\title{
A JÖVŐ KIHÍVÁSAI HOGYAN FOGJÁK ÁTALAKÍTANI LAKÓTEREINKET?
}

\section{HOW WILL THE FUTURE CHALLENGES CHANGE OR LIFE AT HOME?}

\author{
Molnár Eszter, ${ }^{1}$ Borsos Ágnes ${ }^{2}$ \\ Pécsi Tudományegyetem, Müszaki és Informatikai Kar, Vizuális Ismeretek Tanszék, Pécs, Magyarország \\ ${ }^{1}$ esztilla11@gmail.com \\ 2agnesborsos@mik.pte.hu
}

\begin{abstract}
Homemaking as a concept is fundamental for all, being the part of life. The foundation of this idea is a key momentum in everyday life. In a city with its growth of population the amount of living spaces as well as the buildings containing these will increase too. In a city green spaces are a matter of high importance regarding their positive impact. In keeping these we give another meaning to the notion of forming living spaces. In the process we concentrate on unused spaces.
\end{abstract}

Keywords: home, land use, London, CLT, new installation .

\section{Összefoglalás}

Az otthonteremtés mindenki számára egy meghatározó fogalom, mely az élet részét képezi. Ennek a megteremtése kulcsszerepet tölt be a mindennapokban. Egy városban, ahol a népesség száma gyarapodik, a lakások és az ezeket befoglaló létesítmények száma is növekedni fog. Azonban egy nagyvárosban fontos szerepet képviselnek a zöld területek különféle jótékony hatásuk miatt, így ezek megtartásával egy újfajta értelmet adtunk a lakóépületek kialakításának, mely során a kihasználatlan területeket tüztük ki célul.

Kulcsszavak: otthon, területhasznositás, London, CLT, új beépítés.

\section{London}

A cikk egy hallgatói pályázat munkáját mutatja be, mely az otthonteremtéssel foglalkozik. Olyan koncepció kialakítása volt a cél, mely rugalmasan formálható, minimális anyag és földfelhasználás mellett, ezen túl pedig megfizethető legyen mindenki számára. A pályázaton Lu Changgel, Zhao Tianyuval és Varjú Katával együtt vettem részt. London egy metropolisz, a városok lélekszámának és méretének növekedésével, a város értékes felületek hasznosításaival egyre kevesebb zöldfelület marad a városokban, ezért a pályázat célja volt, hogy ne csak új lakás, hanem zöldfelület is kerüljön kialakításra. A pályázat kiírói nem adtak meg tervezési helyszínt, a pályázóknak kellett javasolni Londonban megfelelő telket/telkeket. A koncepció alkotás során a vertikális építkezést választottuk, azért, hogy a városok méretét kevésbé növeljék az újonnan kialakításra kerülő lakások. Helyszínválasztásnál cél volt az, hogy olyan területet válasszunk, amely tömegközlekedési csomóponthoz közel helyezkedik el, így biztosítva a fenntartható közlekedést a városban. A tömegközlekedési csomópontok javarészt jól kiépítettek és kihasználtak, kevés a szabadon álló terület, ezért azt a koncepcionális döntést hoztuk meg, hogy a lakásokat, bevásárlóközpontok tetejére építjük, így kihasználva nagy terjedelmüket, de viszonylag alacsony épületmagasságukat. Az építészeti válasz a pályázati felhívásra az lett, hogy a lakásokat a bevásárló központok tetejére helyeztük el, így nem használva fel a szabad területeket. A koncepciós ábráinkon is látszik, hogy gondol- 
kodásmódunknak köszönhetően valami más is kialakulhat nem csak egy otthonként kialakított épület.(1. ábra)

A bevásárlóközpontok lapostetőinek kihasználása racionális döntés lehet, az épületek területe miatt. Az így kialakuló „új” városi színtér bizonyos esetekben a szmoghatár felett helyezkedhet el, ami gyalogos és biciklis forgalom számára lenne kialakítva. Azzal, hogy ezen a szinten nem jelennek meg a gépjárművek létre jöhet egy szabad gyalogos forgalmat biztosító közlekedési rendszer. Előképe ennek a térszintnek a New York-i High Line volt, ahol az anno emelt térszinten elhelyezett tömegközlekedést alakították át, parkká.

\section{Szerkezet}

A helyszín kiválasztása után, a szerkezeti választás következett. Az épületek telepítése megkíván egy környezettudatos építési módot is, így egy olyan rendszer mellett döntöttünk, amely „újra termelődik” és a lehető legkevésbé károsítja azt. Fontosnak tartottuk a környezet értékeinek hasznosítását, így csökkentve az ökológiai lábnyomunk méretét és a később kialakuló fenntartási költségeket. A CLT ( Cross Laminated Timber) anyag mellett döntöttünk, ami ragasztott tömörfa szerkezet. A kereszt irányú ragasztásnak köszönhetően a faanyag teljes mértékben felhasználható szerkezeti, teherhordó anyagként. Fa vázat alakítottunk ki, amely igénynek megfelelően, tudja fogadni a lakódobozokat, így létrehozva a lakótereket az épületben. A dobozok méretei eltérőek, családmodellhez illeszthető, melyeket az épületvázban bárhol el lehet helyezni. A tömeg kontúrját a vázszerkezet adja, amely egy üres térháló. Ebben jelennek meg a dobozok a lakóterekkel és együtt válnak egy épületté. (2. ábra)

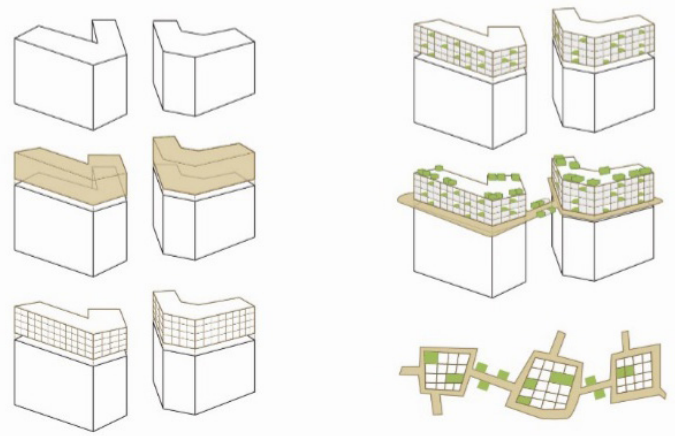

1. ábra. Épület koncepciókialakítása
Egyik inspirációnk Kurokava Kisho kapszula hotelje volt, egy ilyen drága metropoliszban az elérhető árat a lakóterek optimalizálásával lehet elérni, ezért célunk a minimális lakótér kialakítása volt, úgy, hogy az komfortos körülményeket biztosítson. A lakótorony kialakításánál további cél volt, hogy eltérő igényeknek és szükségleteknek megfeleljen, ezért eltérő alaprajzi megoldásokat terveztünk. Az alaprajzok 2 méter x 2 méteres modulrendszerhez igazodnak, így biztosítva azt, hogy vázszerkezethez igazodjanak a lakások. (3. ábra)

Tervünkben igyekeztünk több lehetőséget feltüntetni az esetleges lakáselhelyezésekről, homlokzati lehetőségekről, illetve a lakások kialakítási módszereiről lakóinak számának függvényében. A homlokzatok változatos kialakítása a variálható lakáselhelyezések miatt lehetséges. Kutatásaink során hasonló megoldást láttunk, melyet Cserba Dezső, Guoth István és Preisinger Jenő alakított ki lakássejtekből álló lakóházként. Az ő rendszerük egy lakáson belül a két külső és egy belső térkialakításon alapult, azonban mindegyik zóna azonos méretben került kialakításra. Terveink során olyan alternatívákat kerestünk, melyek magába foglalják a lakáskialakítások különböző lehetőségeit, vagyis a lakásokon belüli térkapcsolatok rendszerét a zöld felülettel való kapcsolatokat, illetve reagálni tud a változó igényekre. A lakások belső tereit változatosan, lakóinak számának megfelelően alakítottuk, formáltuk ezeket összevetve a már említett moduláris rendszert alakítottunk ki. Egyes lakástípusoknál megjelennek az intim terek teljes elkülönülései, azonban néhánynál csak optikai hatással történik meg ez az elválasztás. Megjelenik a bejáratban egy megérkezési zóna, illetve néhány funkciókapcsolat összemosódik pl: nappali átalakulhat alvásra alkalmas helyiséggé. A belső terek szervezésénél a megnyitás meghatározó volt, hogy minden helyiség kellő
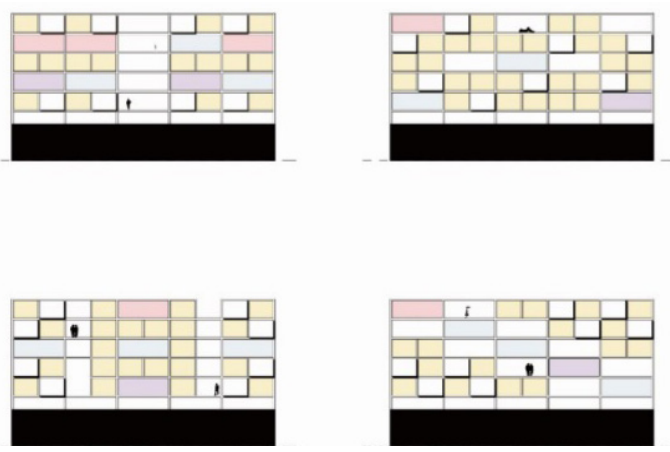

2. ábra. Tömegkialakítási lehetőségek 


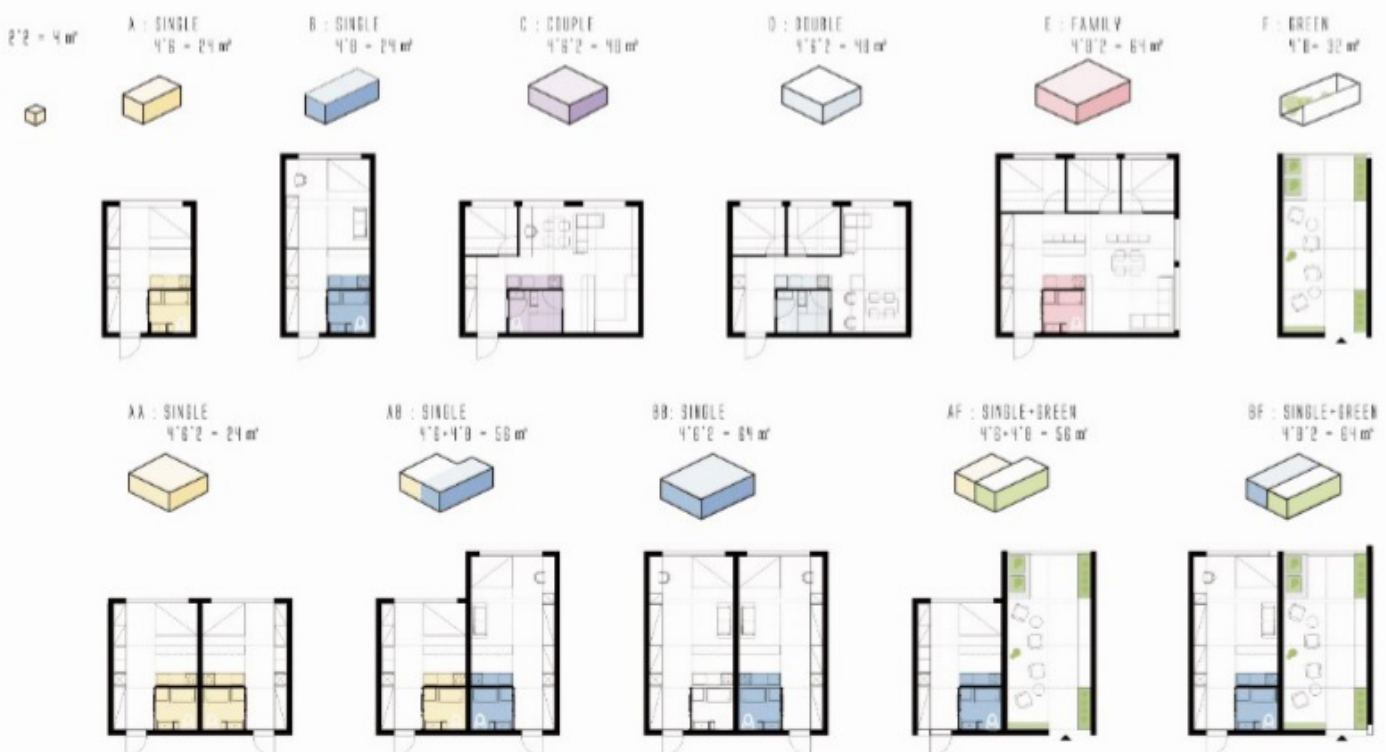

3. ábra. Alaprajzi modulrendszer kialakítása

mennyiségű természetes fényt kapjon. A lakások kialakult belső terei határozzák meg a befoglaló dobozok méretét. A környezettudatos tervezést nem csak a szerkezeti megoldásoknál tartottuk fontosnak, hanem a fenntartásnál is, szélturbinákat helyeztünk el az épületek optimális homlokzati síkjain. A természeti erőforrások optimális felhasználása csökkentheti a fenntartási költségeket, mely a megfizethető otthon egyik alappillére lehet. (4. ábra)

A projekt keretében cél volt városi zöldfelületek kialakítása az épületen belül is. Szerkezeti kontúron belül megjelennek zöldfelületek, melyek

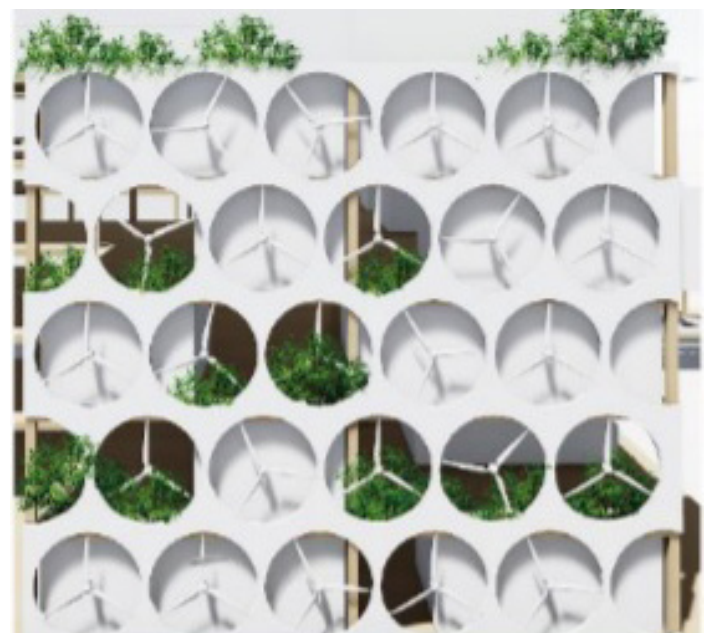

4. ábra. Szélturbinák és zöldfelületek megjelenítése jó hatással vannak az emberi környezetre és az épület energetikája szempontjából is előnyökkel rendelkezik, ez a hőtároló tömeg. A növények jótékony hatással vannak az emberek szellemi és fizikai állapotára, illetve az épületek szempontjából klimatikus és pormegkötő feladatuk is fontos. Ezek a felületek és a lakásokat magukba foglaló dobozok alkotják az épületek homlokzatait. A CLT rendszer egy előre gyártott építési mód, amely előnye, hogy gyorsanmegépíthető és helyszíni szerelése, kivitelezése pontos és egyszerü. (5. ábra)

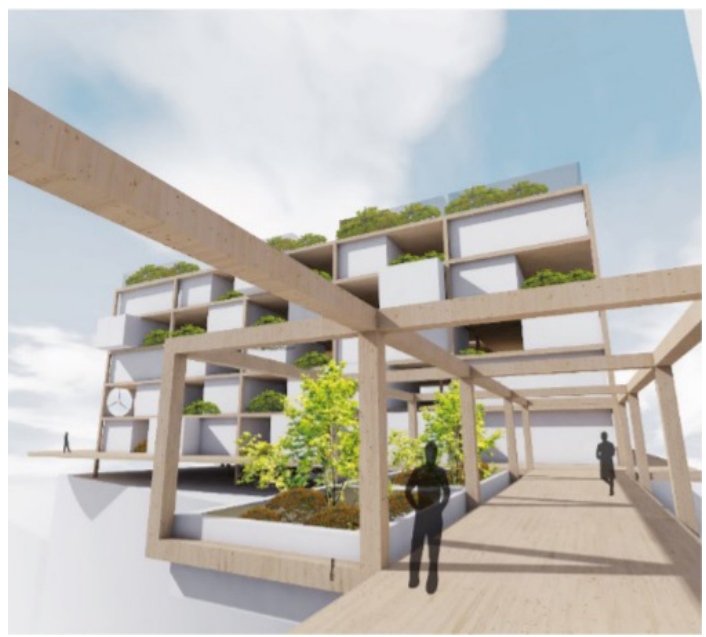

5. ábra. CLT rendszerrel készült épület 


\section{Következtetések}

A tervezési munkát kutatás előzte meg, megvizsgáltam a múlt és jelen lakásállományát nemzetközi és magyar szinten egyaránt. Feltérképeztem ezeknek a lakásoknak a pozitív megoldásait, és összegyüjtöttem azok hátrányait egyaránt. Célom az volt, hogy ezeket a leszürt tapasztalatokat alkalmazzam ilyen hagyományostól eltérő megoldások esetén is, hogy a jövő lakása ember központú, komfortos és előremutató legyen. Minden új építés terheli környezetünket. A természettől veszünk el területeket. Tervezési koncepciónkban törekedtünk a már meglévő úgynevezett „, talált tereket” újra értelmezni azért, hogy új értéket teremtsünk ezzel anélkül, hogy új területet használjunk fel. A nagyvárosi lét újabb és újabb kihívás elé állítja a városlakókat, a beépítésre alkalmas területek mennyisége folyamatosan csökken, ezáltal az ingatlanok értéke és ára nő. A meglévő épületállomány újra értelmezése és felülvizsgálata, a jövő lakásteremtésénél fontos lehet annak érdekében, hogy megfizethető lakásokat lehessen építeni.

\section{Köszönetnyilvánítás}

Az Emberi Erőforrások Minisztériuma ÚNKP-18-2-IPTE-205 kódszámú Új Nemzeti Kiválóság Programjának támogatásával készült.

\section{Szakirodalmi hivatkozások}

[1] Branczik M., Keller M.: Korszerü lakás az óbudai kísérlet 1960. TERC Kft, Nudapest 2011

[2] Pogány F.: A szép emberi környezet. Gondolat könyvkiadó, Budapest, 1976.

[3] Körner Zs., Nagy M.: Az európai és magyar telepszerü lakásépítés története 1945-től napjainkig. TERC Kft., Budapest, 2007.

[4] Kortárs magyar építészet. Többlakásos házak. TERC Kft., Budapest, 2012. 